


\section{Vergelijkend onderzoek naar de gebruikswaarde van zes rassen van de Canadapopulier (Populus x canadensis)}

Hinke Wiersma, Paul Copini \& Joukje Buiteveld

Dit onderzoek is uitgevoerd door CGN, in opdracht van en gefinancierd door de Raad voor plantenrassen, in het kader van het Cultuur- en Gebruikswaardeonderzoek (CGO) t.b.v. de Rassenlijst Bomen, maar geschiedt onder verantwoordelijkheid van de auteur(s) en vertegenwoordigt niet noodzakelijkerwijs de mening van de Raad. 
Wiersma, H., P. Copini, J. Buiteveld, 2020. Vergelijkend onderzoek naar de gebruikswaarde van zes rassen van de Canadapopulier (Populus $x$ canadensis). Centre for Genetic Resources, the Netherlands (CGN), Wageningen University \& Research, CGN rapport 51.22 blz.; 4 fig.; 2 tab.; 20 ref.

Dit rapport presenteert de resultaten van een vergelijkend gebruikswaardeonderzoek van zes rassen van de Canadapopulier (Populus x canadensis) uit Nederland en Frankrijk, met als doel een aanbeveling te doen over het toelaten van de rassen Polargo en Sanosol tot de categorie 'getest uitgangsmateriaal' $(T)$ op de Rassenlijst Bomen. Het onderzoek is uitgevoerd op één proefveldlocatie in het Horsterwold in de provincie Flevoland (Nederland). De eigenschappen die geëvalueerd zijn, betreffen overleving, groei (hoogte en diameter), houtdichtheid en vals kernhout.

This report presents the results of a comparative trial (Value for Cultivation and Use (VCU) of six Euramerican poplar clones (Populus $x$ canadensis) from the Netherlands and France with the aim of making a recommendation on the registration of the clones Polargo and Sanosol in the Tested category of the National Register of Approved Basic Material. The research was conducted at one trial site in the Horsterwold in the province of Flevoland, the Netherlands. The traits that are evaluated concern survival, growth (diameter and height), wood density and false heartwood.

Dit rapport is gratis te downloaden op http://doi.org/10.18174/539001 of op www.wur.nl/cgn onder CGN rapporten.

(C) 2020 Centre for Genetic Resources, the Netherlands (CGN), Wageningen University \& Research E cgn@wur.nl

Wageningen University \& Research aanvaardt geen aansprakelijkheid voor eventuele schade voortvloeiend uit het gebruik van de resultaten van dit onderzoek of de toepassing van de adviezen.

Alle rechten voorbehouden. Niets uit deze uitgave mag worden vermenigvuldigd en/of openbaar gemaakt worden door middel van druk, fotokopie, microfilm of op welke wijze dan ook zonder voorafgaande toestemming van de uitgever of auteur.

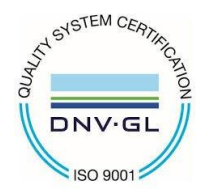

De certificering volgens ISO 9001 onderstreept ons kwaliteitsniveau. 


\section{Inhoud}

Woord vooraf $\quad 5$

$\begin{array}{ll}\text { Samenvatting } & 7\end{array}$

1

$\begin{array}{lr}\text { Inleiding } & 9\end{array}$

2

$\begin{array}{lr}\text { Materiaal \& methode } & 11\end{array}$

2.1 Materiaal $\quad 11$

2.2 Proefopzet 11

2.3 Waarnemingen 11

2.4 Data-analyse $\quad 12$

3

$\begin{array}{ll}\text { Resultaten } & 13\end{array}$

3.1 Overleving 13

3.2 Groei 13

$\begin{array}{lll}3.3 & \text { Houtdichtheid } & 15\end{array}$

$\begin{array}{lll}3.4 & \text { Vals kernhout } & 16\end{array}$

$4 \quad$ Discussie en aanbevelingen $\quad 17$

$\begin{array}{lll}4.1 & \text { Overleving en groei van Polargo en Sanosol } & 17\end{array}$

4.2 Overleving en groei van Hees, Ellert en Koster 17

4.3 Dichtheid en vals kernhout $\quad 18$

4.4 Aanbevelingen Rassenlijst Bomen $\quad 18$

$\begin{array}{ll}\text { Literatuur } & \mathbf{2 0}\end{array}$ 



\section{Woord vooraf}

In dit rapport worden de resultaten gepresenteerd van een vergelijkend gebruikswaardeonderzoek van zes rassen van de Canadapopulier (Populus x canadensis) uit Nederland en Frankrijk. De relatief nieuwe rassen Polargo en Sanosol zijn sinds 2007 toegelaten tot de categorie 'gekeurd uitgangsmateriaal' (Q) op de Rassenlijst Bomen. Om te beoordelen of deze rassen eventueel toegelaten kunnen worden tot de kwalitatief hogere categorie 'getest uitgangsmateriaal' $(T)$, werd in 1998 een proef aangelegd, waarin ook de rassen Robusta, Koster, Ellert en Hees zijn opgenomen. De overleving en groei zijn beoordeeld en worden gepresenteerd. Daarnaast worden resultaten van houtdichtheid- en vals kernhoutbepalingen weergegeven. Het onderzoek maakt deel uit van het Cultuur- en Gebruikswaarde Onderzoek (CGO), dat als basis dient voor de Rassenlijst Bomen. Het Centrum voor Genetische Bronnen Nederland (CGN) heeft dit onderzoek uitgevoerd, in opdracht van de Raad voor plantenrassen (Rvp).

Wij bedanken Staatsbosbeheer (SBB), specifiek Vincent Troost en Jan van Veen, voor het onderhouden van het proefveld. Verder bedanken wij alle medewerkers en studenten van Wageningen University \& Research die hebben bijgedragen aan het onderzoek door het doen van waarnemingen in het proefveld, te weten: Otto Vaessen, Toon Helmink, Roberto Stelstra, Marina Fijten, Judith van Tol en Leo Goudzwaard. Voor de statistische ondersteuning bij het analyseren van de data bedanken wij Paul Goedhart. Ten slotte bedanken we Sven de Vries voor het becommentariëren van het concept van dit rapport. 


\section{Samenvatting}

De Canadapopulier (Populus x canadensis), het resultaat van kruisingen tussen de Amerikaanse populier ( $P$. deltoides) en de Europese zwarte populier ( $P$. nigra), is een veel toegepaste en snelgroeiende hybride in Nederland. In 2007 zijn de rassen Polargo en Sanosol in Nederland toegelaten tot de categorie 'gekeurd uitgangsmateriaal' (Q) op de Rassenlijst Bomen. Om te beoordelen of deze rassen in aanmerking kunnen komen om toegelaten te worden tot de categorie 'getest uitgangsmateriaal' ( $T$ ), is in 1998 een proef aangelegd in het Horsterwold in de Flevopolder. Naast de rassen Polargo en Sanosol zijn ook de rassen Koster, Ellert, Hees en Robusta aangeplant. Vervolgens is de overleving in 2002 bepaald, de hoogte in 2002 en 2019 en de diameter in 2002, 2013 en 2019. Daarnaast is in 2019 de houtdichtheid (juveniel en volwassen) en in 2018 het percentage vals kernhout bepaald.

De resultaten laten zien dat Polargo een hoog overlevingspercentage (87\%) heeft en een significant betere groei (hoogte en diameter) dan Robusta. De groei van Polargo is vergelijkbaar met Ellert en Koster, die samen met Polargo qua groei het beste presteren van alle in deze proef opgenomen rassen. Sanosol heeft een significant lager overlevingspercentage (74\%) dan het gemiddelde over alle rassen in deze proef. Qua groei presteert het ras op jonge leeftijd (ca. vijf jaar na aanleg) significant beter dan Robusta en op oudere leeftijd is dit ras vergelijkbaar met Robusta en Hees. Op basis van de groeikwaliteit worden beide rassen aanbevolen om toegelaten te worden tot de categorie 'getest uitgangsmateriaal' $(T$ ) op de Rassenlijst Bomen, aangezien beide rassen gelijk aan of beter presteren dan Robusta. Tevens bevestigen de resultaten van dit onderzoek de goede groeikwaliteit van Koster, Ellert en Hees. Qua houtkenmerken (houtdichtheid en vals kernhout) zien we weinig verschillen tussen de rassen in deze proef. Daarnaast wordt aanbevolen om proeven aan te leggen met nieuwe rassen, met onder meer de Nederlandse rassen Albelo en Degrosso en verschillende recentelijk uitgegeven Belgische en Franse rassen, om hun gebruikswaarde te beoordelen op basis waarvan deze rassen in aanmerking zouden kunnen komen om toegelaten te worden tot de categorie 'getest uitgangsmateriaal' (T) op de Rassenlijst Bomen. 


\section{$1 \quad$ Inleiding}

De Canadapopulier (Populus x canadensis Moench), ook wel bekend als Canadese of Euramerikaanse populier, betreft een kruising tussen de Amerikaanse populier ( $P$. deltoides) en de Europese zwarte populier ( $P$. nigra). De eerste hybriden in Europa zijn in de $18^{\mathrm{e}}$ eeuw beschreven en vanaf ca. 1770 aangeplant in Nederland (Terrasson and Valadon, 1998, Puijenbroek, 1969). Nadien zijn er door wereldwijd veredelingsonderzoek vele kunstmatige kruisingen geproduceerd met superieure groei, goede ziektetolerantie en stamvorm ten opzichte van de oudersoorten (Stanton et al., 2014). Vanwege snelle groei en rijk strooisel is de Canadapopulier een goede pionier voor de aanleg van nieuwe bossen, die ook nog eens waardevol hout oplevert (Verstraeten et al., 2003, Stanton et al., 2014). Ook kan de houtige biomassa worden omgezet in chemicaliën, medicijnen en energie (Sannigrahi et al., 2010). De hybride wordt ook veelvuldig aangeplant langs wegen, in brede lanen en als solitair in het landschap (Van Haaren, 1987).

Canadapopulieren groeien vooral goed op vochtleverende, vruchtbare en (licht) kalkhoudende bodems (Rassenlijst Bomen, 2020, Van Haaren, 1987). Op zwaardere kleibodems groeit de hybride ook nog steeds goed. Verder is de hybride weinig schaduwtolerant en staat daardoor bekend als een zgn. 'lichthoutsoort'. De Canadapopulier is minder tolerant tegen droogte, maar is aan de andere kant wel tolerant tegen waterstagnatie, vooral in de groeiperiode (Rassenlijst Bomen, 2020, Van Haaren, 1987). De gevoeligheid van Canadapopulieren voor wind verschilt per ras. Ook voor ziekten, zoals roest (Melampsora larici-populina), bladvlekkenziekte (Marssonina brunnea) en bacteriekanker (Xanthomonas populi) verschilt de tolerantie per ras (Steenackers, 2012, Rassenlijst Bomen, 2020). Rassen van de Canadapopulier worden vegetatief vermeerderd (door winterstek) en zijn dus klonen van één enkele ouderboom.

Op basis van klonenproeven zijn in het verleden verscheidene rassen van de Canadapopulier geselecteerd en uitgegeven (Koster, 1990, Kranenborg and De Vries, 1998, Stanton et al., 2014). Momenteel staan er veertien rassen aanbevolen op de Rassenlijst Bomen. De meeste rassen (10) zijn getoetst in meerdere klonenproeven en zijn toegelaten tot de categorie 'getest uitgangsmateriaal' (De Vries, 1988). Vier rassen zijn in 2007 toegelaten tot de categorie 'gekeurd uitgangsmateriaal' (Rassenlijst Bomen, 2020). Deze zijn destijds geselecteerd op basis van ziektetolerantie en groei.

In 1998 is er door het Centrum voor Genetische Bronnen (CGN) een proef opgezet om de gebruikswaarde van de rassen Polargo en Sanosol te vergelijken met de rassen Robusta (referentie), Koster, Ellert en Hees. Dit is gedaan op basis van overlevings- en groei-eigenschappen. Daarnaast zijn van deze rassen de houtdichtheid en het percentage vals kernhout bepaald als belangrijke kenmerken voor het evalueren van de mogelijke gebruikstoepassingen van het hout. Bijvoorbeeld een hoge houtdichtheid en een laag percentage vals kernhout maakt het hout geschikter voor constructiedoeleinden. Het doel van het onderzoek is om de prestatie van de twee relatief nieuwe rassen Polargo en Sanosol in een proef te vergelijken met een aantal bekende handelsrassen (Robusta, Koster, Ellert en Hees). De onderzoeksvraag is dan ook: kunnen de rassen Polargo en Sanosol eventueel toegelaten worden tot de categorie 'getest uitgangsmateriaal' op de Rassenlijst Bomen op basis van de groeikwaliteit in vergelijking met Robusta ${ }^{1}$ (referentie)?

Polargo en Sanosol zijn beide vrouwelijke rassen. Polargo is een kruising van een $P$. deltoides uit België x een $P$. nigra uit Italië als moeder met een $P$. nigra uit Heesselt (Nederland) als vader. Sanosol is een kruising van een $P$. deltoides uit België $\mathrm{x}$ een $P$. nigra uit Italië als moeder met een $P$. nigra uit Brummen (Nederland) $x$ een $P$. nigra uit Italië als vader. Ze zijn goed bestand tegen wind en kunnen daardoor ook worden aangeplant in het kustgebied. Bij en in woonwijken zijn deze beide rassen

\footnotetext{
1 Robusta dient als referentie, omdat dit een lang bekend ras is waarvan de kwaliteit bekend is en meerdere malen onderzocht. Bovendien is het ras veelvuldig gebruikt als referentie in verschillende onderzoeken naar rassen van de Canadapopulier.
} 
minder geschikt, omdat ze jaarlijks vruchtpluis vormen vanaf ongeveer 9-jarige leeftijd, wat veelal als hinderlijk wordt ervaren door de bewoners (Rassenlijst Bomen, 2020). Op het gebied van ziekten kan gesteld worden dat beide rassen goed bestendig zijn tegen roest, Marssonina en bacteriekanker (Steenackers, 2012, Rassenlijst Bomen, 2020).

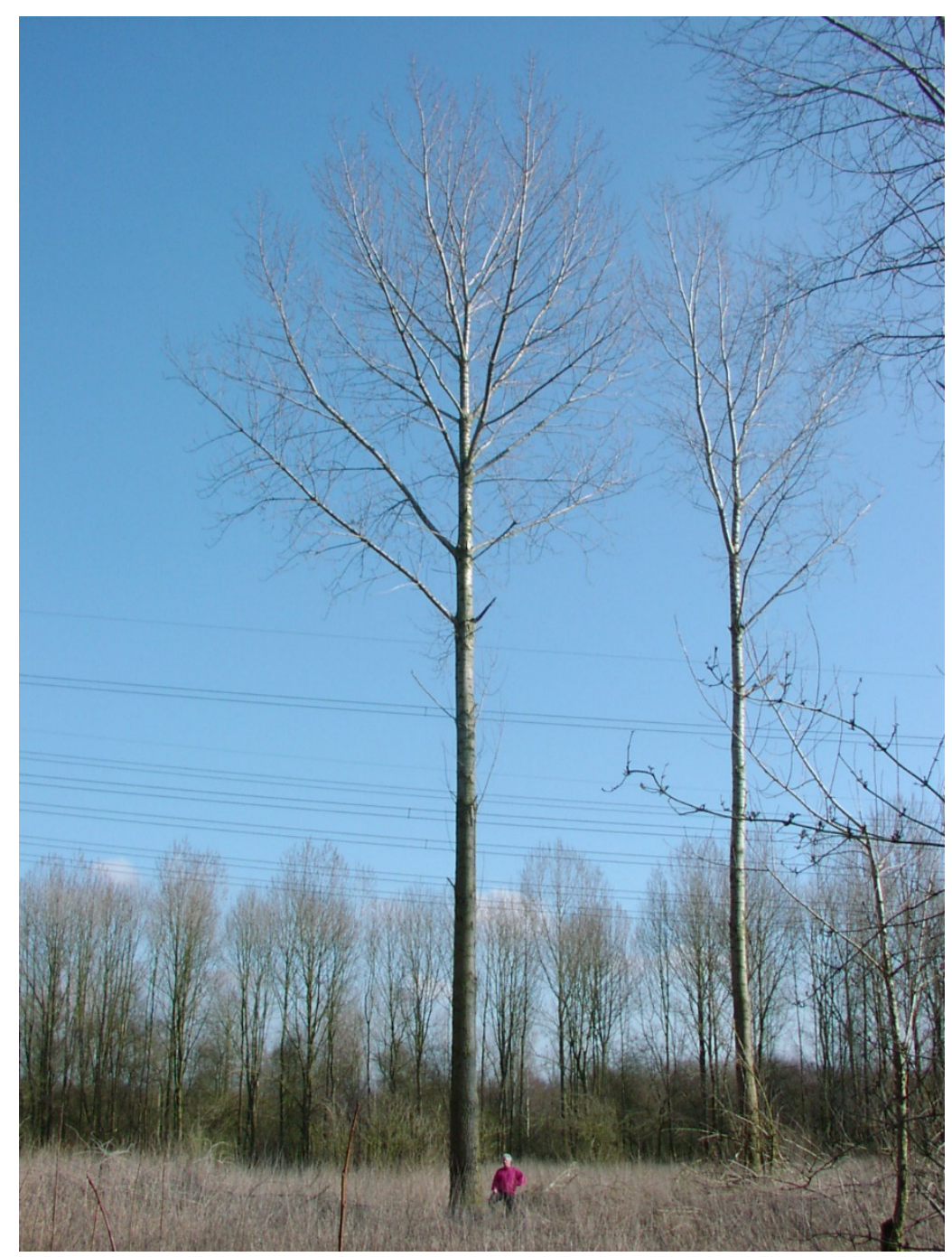

Foto 1.1 Polargo op 24-jarige leeftijd in het Hulkesteinse bos. 


\section{Materiaal \& methode}

\section{$2.1 \quad$ Materiaal}

In de proef zijn zes rassen (en twee experimentele klonen) aangeplant van de Canadapopulier (Populus $x$ canadensis Moench). Deze zes rassen (Tabel 2.1) zijn in de Rassenlijst Bomen toegelaten tot de categorie gekeurd (Polargo en Sanosol) of getest uitgangsmateriaal (Hees, Ellert, Koster en Robusta) (zie ook www.rassenlijstbomen.nl). De twee experimentele klonen (7939 en 10670) zijn nooit uitgegeven, gezien hun slechtere overleving, stamvorm en/of groei. Deze twee klonen worden voor deze studie verder buiten beschouwing gelaten. Robusta wordt in deze proef als referentie gebruikt.

Tabel 2.1 De rassen van Canadapopulier opgenomen in de proef (Rassenlijst Bomen, 2020, Steenackers, 2012).

\begin{tabular}{|c|c|c|c|c|c|c|}
\hline Ras & Op Rassenlijst sinds & $\begin{array}{l}\text { Categorie } \\
\text { uitgangsmateriaal }\end{array}$ & Geslacht & $\begin{array}{l}\text { Roestgevoe- } \\
\text { ligheid }\end{array}$ & $\begin{array}{l}\text { Bladvlek- } \\
\text { kenziekte }\end{array}$ & Bacteriekanker \\
\hline Robusta & 1970 (4e Rassenlijst) & $\mathrm{T}$ getest & Mannelijk & Matig & Goed & Goed \\
\hline Ellert & 1990 (5e Rassenlijst) & $T$ getest & Mannelijk & Goed & Goed & Zeer goed \\
\hline Hees & 1990 (5 Rassenlijst) & $T$ getest & Vrouwelijk & Goed & Goed & Zeer goed \\
\hline Sanosol & 2007 (8 Rassenlijst) & Q gekeurd & Vrouwelijk & Goed & Goed & Goed \\
\hline
\end{tabular}

\subsection{Proefopzet}

Het proefveld is aangelegd op 22 januari 1998 in het Horsterwold (Staatsbosbeheer, vak 267 K4, coördinaten $52.324365^{\circ} \mathrm{N}, 5.453999^{\circ} \mathrm{E}$ ) met eenjarig bewortelde stek $(0+1)$ geteeld op de kwekerij van de Dorschkamp. Het proefveld is aangelegd op een voormalige kapvlakte van populier op een kalkrijke poldervaaggrond met lichte klei (Mn35A). Het gaat om een inorthogonale blokkenproef met drie herhalingen (blokken). In elke herhaling komen alle rassen voor, behalve Polargo (twee herhalingen). Voor elk ras, in elke herhaling, zijn 24 planten (4x6) per ras geplant (een plot) met een plantverband van $6 \times 5 \mathrm{~m}$. Rondom de proef is een randrij geplant van populier. Doordat de plantgaten in de rijen niet altijd precies geboord zijn op een afstand van $5 \mathrm{~m}$, staan de bomen in noord-zuid richting niet goed in rechthoeksverband. Om mogelijke fouten te voorkomen, zijn er geen waarnemingen gedaan aan bomen die op de grens stonden tussen twee plots (dus 4x4, 16 planten per plot) of is er aan de hand van het tijdstip van bladuitloop gecontroleerd of het om het juiste ras ging. In 2014 is er gedund in het proefveld.

\subsection{Waarnemingen}

In 2002, ca. 5 jaar na aanleg, is het overlevingspercentage per ras bepaald. Dit betreft per ras het aantal levende bomen in 2002 ten opzichte van het totaalaantal aangeplante bomen per ras bij de aanleg van het proefveld. De groei (hoogte, diameter) is in drie verschillende jaren gemeten: december 2002, najaar 2013 en voorjaar 2019. Dit is respectievelijk ca. 5, 16 en 21 jaar na de aanleg van het proefveld. In 2002 is de diameter met de boomklem gemeten en de hoogte met de telescoopstok. In 2013 is de diameter met een boomklem gemeten. In 2019 is de hoogte gemeten met een Nikon forestry pro (optische hoogtemeter) en de diameter met een pi-band op borsthoogte (dbh). 
Daarnaast zijn er houtkenmerken beoordeeld, namelijk de houtdichtheid voor juveniel en volwassen hout en het percentage vals kernhout. In het voorjaar van 2019 zijn vijf houtmonsters per ras genomen voor het bepalen van de houtdichtheid (juveniel en volwassen hout) van de verschillende rassen met een aanwasboor (40cm Haglöf). In het lab zijn vervolgens het drooghoutgewicht (24 uur drogen bij $105^{\circ} \mathrm{C}$ ) en het volume (waterverplaatsing in natte en droge omstandigheden) bepaald om de houtdichtheid te berekenen. Voor het bepalen van het percentage stamoppervlak van het valse kernhout van de verschillende rassen zijn er op 4 juli 2018 twee boorkernen genomen met een hoek van $90^{\circ}$ ten opzichte van elkaar op $80 \mathrm{~cm}$ stamhoogte voor 8 bomen per ras. Aangezien het middelpunt van de boom niet altijd aanwezig is in de boorkern, is de diameter van het valse kernhout berekend door de diameter van het spinthout af te trekken van de algehele diameter gemeten op $80 \mathrm{~cm}$ stamhoogte, waarbij de diameter van de bast, gebaseerd op de boorkernen, eerst van de algehele diameter is afgetrokken. Vervolgens is het percentage stamoppervlak van vals kernhout berekend aan de hand van het stamoppervlak vals kernhout en het gehele stamoppervlak.

\subsection{Data-analyse}

De analyses voor overleving, hoogte en diameter van de rassen voor de verschillende jaren zijn uitgevoerd in $\mathrm{R}$ (versie 1.3.959). De volgende 'R packages' zijn gebruikt voor het uitvoeren van de analyses: ordinal (2019.12-10), emmeans (1.5.1), multcomp (1.4-14), Ime4 (1.1-23) en pbkrtest (0.4-8.6). Met een logistisch regressiemodel zijn de binaire overlevingsdata geanalyseerd; hierbij is gekeken naar het gemiddelde overlevingspercentage per ras ten opzichte van het proefveldgemiddelde. Er is gebruikgemaakt van het uitrekenen van de contrasten door middel van de least-square means met een onbetrouwbaarheidsdrempel van $5 \%$, waarbij niet is gecorrigeerd voor het aantal toetsen dat is gedaan in de analyse. De hoogte- en diameterdata van de verschillende jaren zijn geanalyseerd door het gebruik van een Lineair Mixed Effect Model. De plot is genomen als experimentele eenheid voor alle analyses. Er is gecorrigeerd voor overdispersie waar dit nodig was. De verschillen in de gemiddelde hoogte en diameter tussen de rassen zijn geanalyseerd door een multiple comparison Tukey-toets, die corrigeert voor het aantal vergelijkingen, met een onbetrouwbaarheidsdrempel van 5\%. De data voor de houtdichtheid zijn met dezelfde toets en onbetrouwbaarheidsdrempel geanalyseerd. De data voor vals kernhout zijn geanalyseerd met een One-way Anova in SPSS. 


\section{Resultaten}

\section{$3.1 \quad$ Overleving}

Het gemiddelde overlevingspercentage van alle rassen is $84 \%$ in 2002, ongeveer 5 jaar na de aanleg van de proef. In Figuur 3.1 is het overlevingspercentage per ras weergegeven. Over het algemeen zijn de bomen in het proefveld goed aangeslagen. In vergelijking met het gemiddelde over alle rassen blijkt dat Sanosol (74\%) een significant lager overlevingspercentage heeft $(p<0,01)$. Verder is te zien dat de rassen Robusta ( $82 \%)$, Hees ( $84 \%$ ) en Polargo $(87 \%)$ op en rond het gemiddelde van alle rassen liggen. De rassen Koster (94\%) en Ellert (98\%) hebben de hoogste overlevingspercentages, waarbij voor Ellert het percentage significant hoger ligt ten opzichte van het gemiddelde $(p<0,05)$.

Overleving rassen 2002

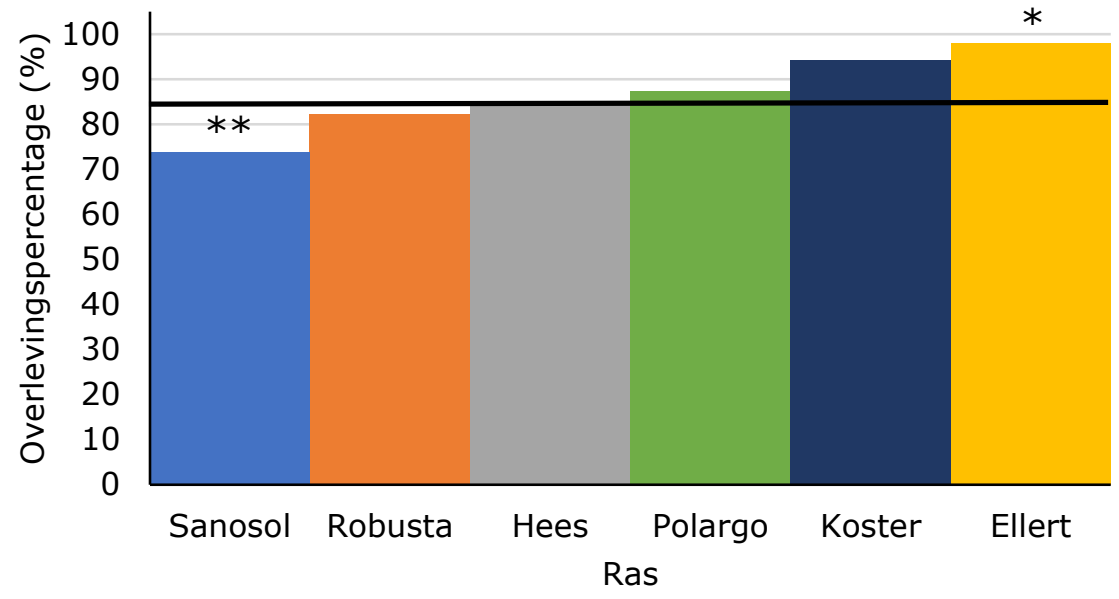

Figuur 3.1 De gemiddelde overleving (\%) van de rassen in 2002. Met de horizontale lijn is het gemiddelde overlevingspercentage van $84 \%$ over alle rassen in het proefveld weergegeven. $P$-waarde $p<0,05\left(^{*}\right)$ en $p<0,01\left(^{* *}\right)$ voor een significante afwijking ten opzichte van het gemiddelde over alle rassen.

\subsection{Groei}

De gemiddelde diameter en hoogte per ras zijn weergegeven in Figuur 3.2. Daarnaast is in de figuur ook aangegeven welke rassen een significant grotere of kleinere hoogte en/of diameter hebben dan de referentie Robusta. In Tabel 3.1 is met percentages weergegeven hoe de rassen zich verhouden tot Robusta. Uit de resultaten blijkt dat Polargo een significant $(p<0,05)$ grotere gemiddelde diameter heeft dan Robusta voor alle drie de jaren, terwijl dit voor Sanosol alleen in 2002 zo is. In 2002, ongeveer 5 jaar na de aanleg, heeft Polargo $(15,8 \mathrm{~cm}$, Figuur 3.2) een bijna $2 x$ zo grote gemiddelde diameter als Robusta $(8,5 \mathrm{~cm})(86 \%$ groter, Tabel 3.1$)$. Sanosol $(11,6 \mathrm{~cm})$ is gemiddeld $3,5 \mathrm{~cm}(37 \%)$ groter in diameter dan Robusta; dit verschil is kleiner dan met Polargo, maar nog wel significant $(p<0,05)$. In 2013 en 2019 heeft Polargo $(36,8 \mathrm{~cm} ; 45 \mathrm{~cm}$ ) een significant grotere gemiddelde diameter dan Robusta $(28,8 \mathrm{~cm} ; 37,1 \mathrm{~cm})$, respectievelijk $28 \%(8,0 \mathrm{~cm})$ en $21 \%(7,9 \mathrm{~cm})$ (Figuur 3.2, Tabel 3.1) groter. In dezelfde jaren heeft Sanosol een diameter die niet significant verschillend is van Robusta. 
Qua hoogtegroei is zowel Sanosol als Polargo significant beter dan Robusta in $2002(p<0,05)$, maar niet in 2019. In 2002 zijn Polargo $(11.3 \mathrm{~m}$ ) en Sanosol $(9.9 \mathrm{~m})$ respectievelijk 3,8 (51\%) en $2,4(32 \%)$ meter hoger ten opzichte van Robusta $(7,5 \mathrm{~m})$. In 2019 is het verschil kleiner en ook niet significant; Polargo is gemiddeld 0,9 (3\%) meter hoger dan Robusta (respectievelijk 27,8 en 26,9 meter) en Sanosol met 27,3 meter, 0,4 (1\%) meter hoger (Tabel 3.1, Figuur 3.2).
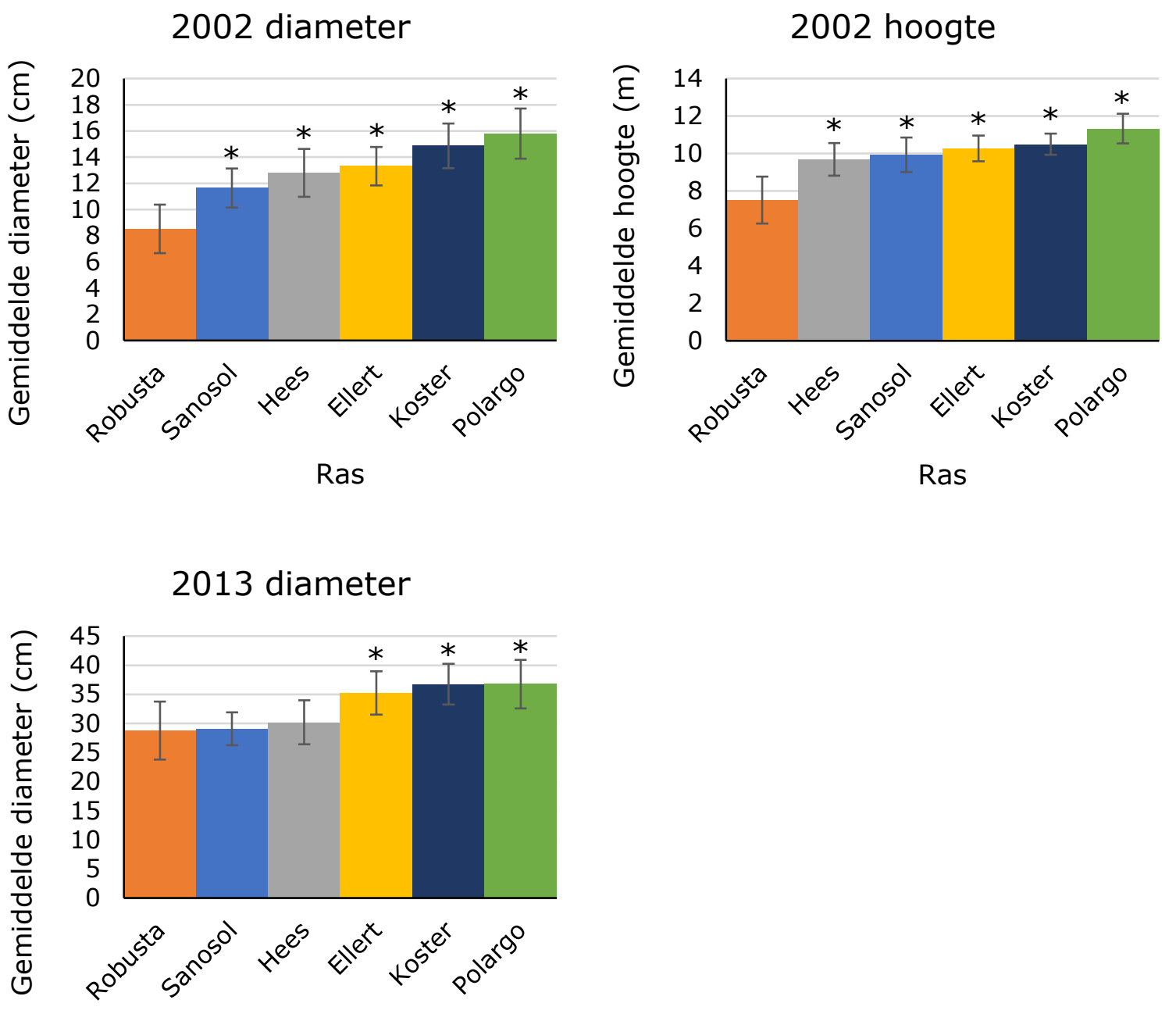

Ras

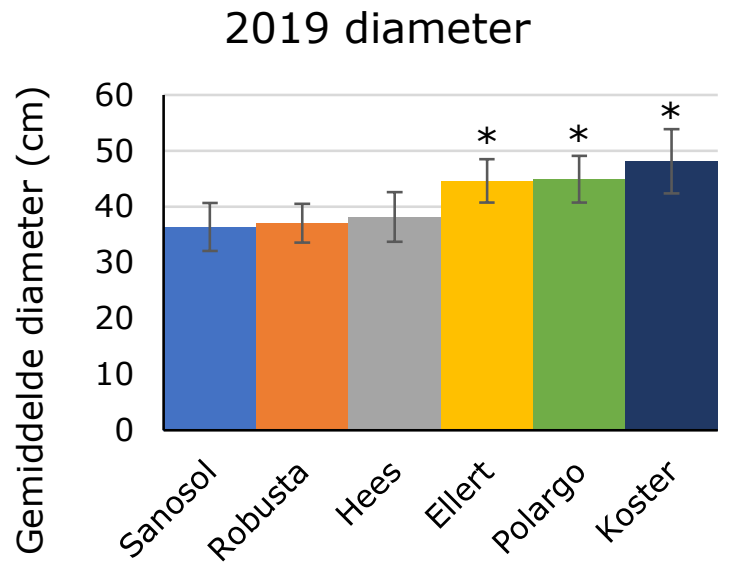

Ras

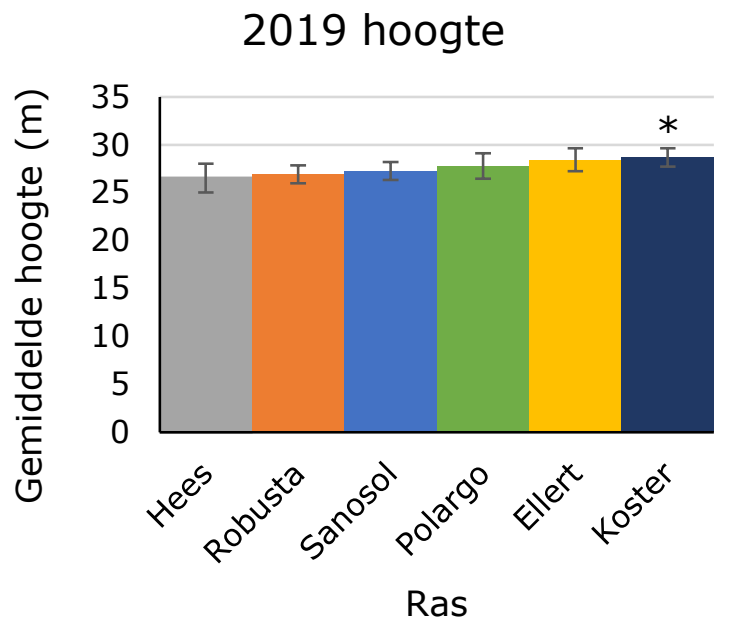

Figuur 3.2 De gemiddelde hoogte en diameter van de rassen voor verschillende jaren met standaarddeviatie $\left( \pm S D\right.$ ) en met $p$-waarde $p<0,05\left(^{*}\right)$ voor het verschil per ras met de referentie Robusta. 
In Figuur 3.2 en Tabel 3.1 is ook te zien dat Polargo een betere groei heeft dan de andere rassen (diameter, hoogte) op jonge leeftijd (ca. 5 jaar na aanleg). Op latere leeftijd (2013/2019) heeft Polargo een grotere gemiddelde hoogte en diameter dan Hees en is vergelijkbaar met de rassen Koster en Ellert voor zowel hoogte als diameter. Sanosol is qua groei vergelijkbaar met Hees en presteert lager qua groei dan Koster en Ellert. Verder laat Figuur 3.2 zien dat Koster voor alle jaren een grotere gemiddelde diameter en hoogte heeft dan Ellert en Hees, waarbij die van Ellert groter is dan die van Hees. Koster, Ellert en Hees hebben een significant hogere gemiddelde hoogte en diameter dan Robusta in 2002. Daarnaast hebben Koster en Ellert in 2013 en 2019 ook een significant hogere diameter dan Robusta en heeft Koster ook een significant hogere gemiddelde hoogte dan Robusta in 2019 (Figuur 3.2).

Tabel 3.1 Gemiddelde hoogte en diameter van de rassen in percentage t.o.v. Robusta voor de verschillende jaren.

\begin{tabular}{|c|c|c|c|c|c|}
\hline & Diameter 2002 & Diameter 2013 & Diameter2019 & Hoogte 2002 & Hoogte 2019 \\
\hline Robusta & $100 \%$ & $100 \%$ & $100 \%$ & $100 \%$ & $100 \%$ \\
\hline Koster & $175 \%$ & $128 \%$ & $130 \%$ & $140 \%$ & $107 \%$ \\
\hline Hees & $150 \%$ & $105 \%$ & $103 \%$ & $129 \%$ & $99 \%$ \\
\hline Polargo & $186 \%$ & $128 \%$ & $121 \%$ & $151 \%$ & $103 \%$ \\
\hline
\end{tabular}

\subsection{Houtdichtheid}

In Figuur 3.3 is de gemiddelde houtdichtheid per ras weergegeven voor zowel volwassen (gemiddeld $371 \mathrm{~kg} / \mathrm{m}^{3}$ over alle rassen) als juveniel (gemiddeld $346 \mathrm{~kg} / \mathrm{m}^{3}$ over alle rassen) hout. Robusta heeft de hoogste houtdichtheid van alle rassen voor zowel juveniel $\left(405 \mathrm{~kg} / \mathrm{m}^{3}\right)$ als volwassen $\left(394 \mathrm{~kg} / \mathrm{m}^{3}\right)$ hout. Voor juveniel hout geldt dat Koster $\left(315 \mathrm{Kg} / \mathrm{m}^{3}\right)$, Ellert $\left(323 \mathrm{~kg} / \mathrm{m}^{3}\right)$, Polargo $\left(336 \mathrm{~kg} / \mathrm{m}^{3}\right)$ en Sanosol $\left(339 \mathrm{~kg} / \mathrm{m}^{3}\right)$ een significant $(p<0,05)$ lagere houtdichtheid hebben dan Robusta $\left(405 \mathrm{~kg} / \mathrm{m}^{3}\right)$. De rassen onderling zijn niet significant verschillend voor de dichtheid van volwassen hout.

\section{Houtdichtheid volwassen}

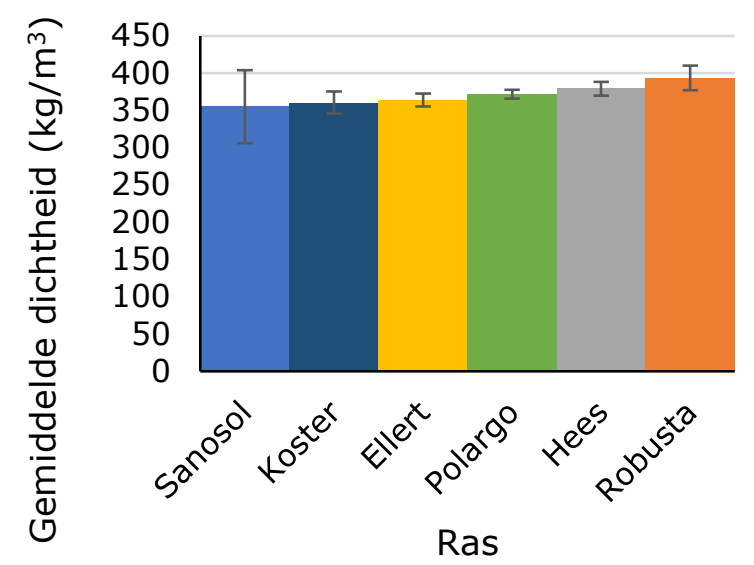

\section{Houtdichtheid juveniel}

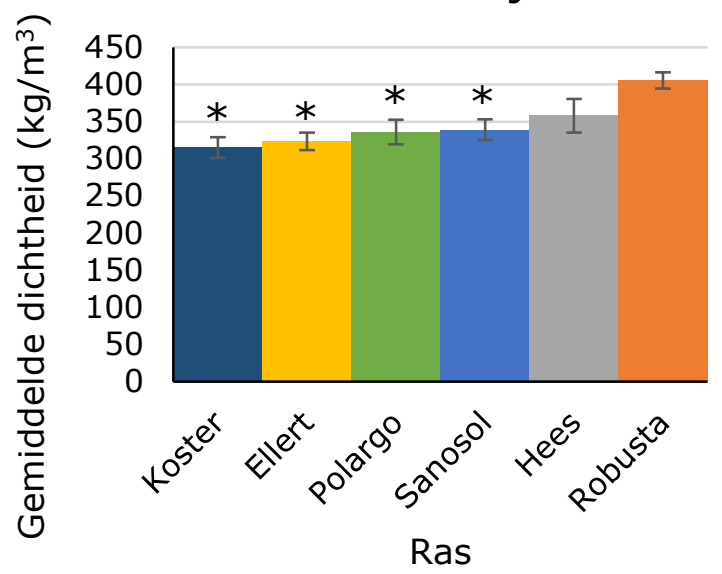

Figuur 3.3 De gemiddelde houtdichtheid van de rassen met standaarddeviatie ( \pm SD) en met $p$-waarde $p<0,05\left(^{*}\right)$ voor het verschil per ras met de referentie Robusta. 


\subsection{Vals kernhout}

In Figuur 3.4 is het vals kernhout weergegeven in percentages. De percentages vals kernhout liggen tussen $51 \%$ (Hees) en $63 \%$ (Ellert). Koster, Robusta en Hees hebben de laagste percentages vals kernhout, respectievelijk 53\%, 52\% en 51\%. Polargo, Sanosol en Ellert hebben iets hogere percentages voor vals kernhout. Ellert heeft significant $(p<0,05)$ meer vals kernhout dan Robusta.

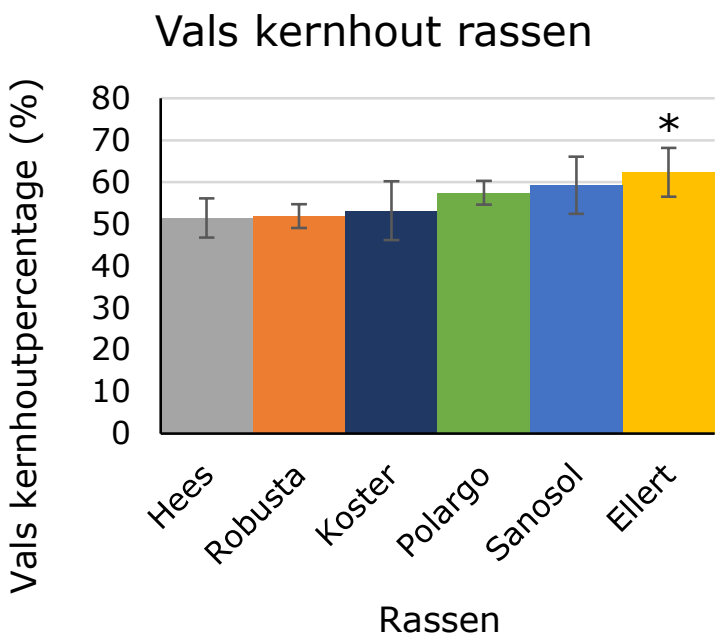

Figuur 3.4 Het gemiddelde vals kernhoutpercentage (\%) van de rassen in 2018 met standaarddeviatie $( \pm S D)$ en met $p$-waarde $p<0,05\left(^{*}\right)$ voor het verschil per ras met de referentie Robusta. 


\section{$4 \quad$ Discussie en aanbevelingen}

Het doel van dit onderzoek is om in een vergelijkende toets de prestatie van twee relatief nieuwe rassen Polargo en Sanosol ten opzichte van een aantal bekende handelsrassen (Robusta, Koster, Ellert en Hees) te beoordelen. Hieronder worden de resultaten van het onderzoek besproken naar de eigenschappen overleving, groei, houtdichtheid en vals kernhout.

\subsection{Overleving en groei van Polargo en Sanosol}

Polargo heeft een hoog overlevingspercentage van $87 \%$, ca. vijf jaar na aanleg van de proef. Tevens kent het ras een goede groei. Polargo heeft een significant hogere gemiddelde diameter en hoogte dan de referentie Robusta voor alle jaren, behalve voor de hoogte in 2019. Bovendien is de groei van Polargo vergelijkbaar met die van Koster, die bekendstaat als een ras van hoge groeikwaliteit (Stanton et al., 2014) en zelfs gemiddeld beter op jongere leeftijd. In het onderzoek van Rahayu et al. (2014) werd gevonden dat de groei van Polargo identiek is aan die van Koster. In de praktijk wordt Polargo ook goed bevonden en veel aangeplant. In België wordt Polargo als een goed ras gezien, vergelijkbaar met Koster, en in Frankrijk is het ras toegelaten tot de categorie 'getest uitgangsmateriaal' ( $T$ ), net zoals Robusta, Koster en Hees (Ministère de l'agriculure et de I'alimentation, 2019, Interreg, 2019). Bovendien werd in Frankrijk in 2015-2016 Polargo, na Koster en één ander ras, het meest gebruikt voor bosaanplant, terwijl Robusta op plek 41 staat (Joyeau and Pierangelo, 2017). Verder biedt het ras ook goede weerstand tegen wind, roest, Marssonina en bacteriekanker (Steenackers, 2012, Rassenlijst Bomen, 2020).

Sanosol heeft een significant $(\mathrm{p}<0,05)$ lagere overleving $(74 \%)$ dan het gemiddelde over alle rassen. Echter, in recente beplantingen van dit ras in het Horsterwold (Flevoland) is geen uitval waargenomen en ook bij eerdere aanplant in proeven is geen hoge uitval genoteerd. Verder presteert Sanosol op jongere leeftijd, ongeveer 5 jaar na de aanleg van de proef, significant beter voor diameter (37\%) en hoogte $(29 \%)$ dan de referentie Robusta in deze proef. Op latere leeftijd is Sanosol vergelijkbaar met Robusta en Hees voor groei. Het ras is vergelijkbaar met Polargo in weerstand tegen wind, roest, Marssonina en bacteriekanker (Rassenlijst Bomen, 2020, Steenackers, 2012). Er is nauwelijks tot geen informatie over de gebruikswaarde van Sanosol in de praktijk vanuit buitenlands onderzoek. Het ras staat bijvoorbeeld niet, zoals Polargo, in de lijst met de 41 meest verkochte populierenrassen in Frankrijk in 2015-2016 (Joyeau and Pierangelo, 2017).

Deze proef en eerdere proeven zijn aangeplant met éénjarige bewortelde stek. Een relatief nieuwe manier van aanplanten in Nederland is het gebruik maken van poten of staken. Op de kwekerij worden gestekte bomen na twee jaar boven de grond afgesneden. Dit resulteert in staken of poten van circa $5 \mathrm{~cm}$ dik en vaak meer dan 4 meter lang. Deze staken of poten, die van een scherpe punt voorzien zijn worden in diepe plantgaten geplant. Bij poten of staken wordt over het algemeen een veel lagere uitval verwacht. De manier van aanplanten (beworteld vs. niet beworteld) kan de overleving van een bepaald ras of kloon beïnvloeden en proefresultaten t.o.v. overleving van een ras of kloon moeten dan ook gezien worden in relatie tot de aanplantmethode.

\subsection{Overleving en groei van Hees, Ellert en Koster}

De overlevingspercentages van Hees, Ellert en Koster zijn hoog, respectievelijk 82\%, 98\% en $94 \%$, waarbij Ellert een significant hogere overleving heeft dan het gemiddelde over alle rassen. In dit proefveld hebben Ellert en Koster een significant betere groei dan Robusta, behalve voor de hoogte in 2019, waar alleen Koster een significant hogere groei laat zien. Hees heeft op jonge leeftijd een significant betere en in de latere jaren een vergelijkbare groei als Robusta. Verder groeien Ellert en 
Koster beter dan Hees, waarbij Koster weer beter groeit dan Ellert. Deze resultaten komen overeen met de groeiresultaten uit de proefvelden Schijndel (lemige fijnzandige bodem) en LZ24 (kleiige IJsselmeer- en Zuiderzeeafzetting) in een vergelijkbaar onderzoek uit 1998 (Kranenborg and De Vries, 1998). Zeven jaar na de aanleg van de proef heeft Koster een betere groei dan Ellert en Hees (welke vergelijkbaar zijn) in Schijndel en heeft Koster een vergelijkbare groei met Ellert en hoger dan Hees in LZ24. Verder presteren Koster, Hees en Ellert beter qua groei dan Robusta op jonge leeftijd in beide proefvelden (Kranenborg and De Vries, 1998), wat ook uit het huidige onderzoek blijkt.

Uit jaarringonderzoek, uitgevoerd in het Dendrolab van de WUR in 2018, bleek dat Koster, Ellert en Hees in het proefveld in Schijndel ook op oudere leeftijd ( $t / m$ 19 jaar na aanleg) een betere groei vertoonden dan Robusta (Stelstra, 2019). Hetzelfde blijkt uit de resultaten van de groeimetingen in het huidige onderzoek, behalve voor Hees, die op oudere leeftijd een vergelijkbare groei met Robusta heeft. In het jaarringonderzoek viel op dat de groei in het proefveld in het Horsterwold (eveneens het proefveld gebruikt voor dit rapport) achterblijft ten opzichte van Schijndel (Stelstra, 2019). Dit komt zeer waarschijnlijk door de late dunning (17 jaar na aanleg) in deze opstand. Dit blijkt ook uit het jaarringonderzoek; de groei van de bomen blijft sterk achter, met een reductie van ca. 50\% in jaarringbreedtes in de periode tussen 2008 en de dunning in 2014 (Stelstra, 2019). Om diametergroei te behouden, is het van belang om populier tijdig te dunnen, in dit geval op 10-jarige leeftijd.

\subsection{Dichtheid en vals kernhout}

Robusta is het ras met een significant hogere gemiddelde houtdichtheid dan Koster, Ellert, Polargo en Sanosol voor juveniel $\left(405 \mathrm{~kg} / \mathrm{m}^{3}\right)$ hout en ook met de gemiddeld hoogste houtdichtheid voor volwassen $\left(394 \mathrm{~kg} / \mathrm{m}^{3}\right.$ ) hout. Dit maakt dit ras ook enigszins meer geschikt voor constructie doeleinden dan de andere rassen (Rahayu et al., 2014, Balatinecz et al., 2014). Gemiddeld was de houtdichtheid voor volwassen hout $371 \mathrm{~kg} / \mathrm{m}^{3}$ over alle rassen en juveniel gemiddeld $346 \mathrm{~kg} / \mathrm{m}^{3}$ over alle rassen. Dit komt overeen met waarnemingen uit onderzoek van De Boever and Van Acker (2003) en Rahayu et al. (2014) waarbij gevonden werd dat de dichtheid van populierenhout varieert tussen 350 en $450 \mathrm{~kg} / \mathrm{m}^{3}$ (bij respectievelijk 12\% en 8-10\% vochtgehalte). Het percentage vals kernhout (op $80 \mathrm{~cm}$ stamhoogte op ong. 20-jarige leeftijd) was het hoogst voor Ellert (62\%, significant hoger dan Robusta) en het laagst voor Koster (53\%), Robusta (52\%) en Hees (51\%). Hoe hoger het percentage vals kernhout, hoe minder geschikt het ras is voor hoogwaardige constructiedoeleinden (Johansson and Hjelm, 2013, Balatinecz et al., 2014, Rahayu et al., 2014).

\subsection{Aanbevelingen Rassenlijst Bomen}

Op basis van de resultaten voor groei-eigenschappen in deze proef worden de rassen Polargo en Sanosol aanbevolen voor een opwaardering door middel van toelating tot de categorie 'getest uitgangsmateriaal'. Polargo heeft een goede groei, die beter is dan de referentie Robusta en vergelijkbaar is met die van Koster en Ellert. De groeikwaliteit van Sanosol is weliswaar niet zo goed als die van Polargo, Koster en Ellert, echter, op jonge leeftijd is de groeikwaliteit significant beter dan de referentie Robusta en op oudere leeftijd is het ras vergelijkbaar met zowel Robusta als Hees. Voor een licht-behoevende soort als populier is een snelle jeugdgroei van groot belang. Bovendien zijn beide rassen goed bestand tegen wind, Marssonina, bacteriekanker en roest (Steenackers, 2012; Rassenlijst Bomen, 2020).

Bij de aanbeveling om Sanosol toe te laten tot de categorie 'getest uitgangsmateriaal' moet opgemerkt worden dat Sanosol voor de eigenschap overleving minder goede resultaten laat zien (overleving significant lager dan proefveldgemiddelde). In recente beplantingen van dit ras in het Horsterwold (Flevoland) wordt echter geen uitval waargenomen en ook bij eerdere aanplant in proeven met bewortelde stek is geen hoge uitval genoteerd. 
Daarnaast bevestigt het rassenonderzoek de toelating van Koster, Ellert en Hees tot de categorie 'getest uitgangsmateriaal'. De groei van deze rassen in het proefveld uit dit onderzoek is vergelijkbaar met de goede groeiresultaten van deze rassen in andere proefvelden. Bovendien presteren deze rassen ook goed op andere eigenschappen, zoals resistentie tegen ziektes (Rassenlijst Bomen, 2020).

Verder wordt aanbevolen om een nieuwe gebruikswaardeproef op te zetten met een ruim assortiment van populierrassen waar momenteel in Nederland belangstelling voor is. Zo kunnen de in Nederland ontwikkelde rassen Albelo en Degrosso (momenteel toegelaten tot de categorie 'gekeurd uitgangsmateriaal') meegenomen worden in een dergelijke proef. Deze rassen worden in praktijkbeplantingen toegepast in o.a. Nederland, België en Frankrijk. Daarnaast zijn er de afgelopen jaren verschillende rassen beschikbaar gekomen vanuit het veredelingswerk van het INBO, zoals Vesten, Muur en Oudenberg uit België (Steenackers et al., 2018) en Rona en Dano vanuit Frankrijk (Interreg, 2019), die veelbelovend zijn in de praktijk en getoetst kunnen worden voor geschiktheid in Nederland. 


\section{Literatuur}

BALATINECZ, J., MERTENS, P., DE BOEVER, L., YUKUN, H., JIN, J. \& VAN ACKER, J. 2014. Properties, processing and utilization. In: ISEBRANDS, J. G. \& RICHARDSON, J. (eds.) Poplars and Willows: Trees for Society and the Environment. Wallingford, Boston: CABI, FAO.

DE BOEVER, L. \& VAN ACKER, J. 2003. Houtkwaliteit en toepassingsmogelijkheden van populier in Vlaanderen. Bosrevue, 5, 11-15.

DE VRIES, S. M. G. 1988. Drie nieuwe populierenklonen. Wageningen: Rijksinstituut voor onderzoek in de bos- en landschapsbouw "De Dorschkamp".

INTERREG. 2019. Populier \& Populicultuur: Voor een duurzame en verantwoorde populierenaanplantingen populier en populierenteelt [Online]. Available: http://bosgroepen.be/wpcontent/uploads/2019/03/Populier-populicultuur.pdf [Accessed 8 December 2020].

JOHANSSON, T. \& HJELM, B. 2013. Frequency of false heartwood of stems of poplar growing on farmland in Sweden. Forests, 4, 28-42.

JOYEAU, C. \& PIERANGELO, A. 2017. Programme 2016 d'appui technique d'Irstea au MAAF dans le domaine des Ressources Génétiques Forestières: volet 1 sur les Matériels Forestiers de Reproduction (synthèse des résultats de l'enquête « statistiques sur la production et la vente de plants forestiers en pépinières - Campagne 2015-2016). Irstea.

KOSTER, R. 1990. Populierenveredeling. Wageningen: Rijksinstituut voor onderzoek in de bos- en landschapsbouw "De Dorschkamp".

KRANENBORG, K. G. \& DE VRIES, S. M. G. 1998. Vergelijkend onderzoek naar de gebruikswaarde van twaalf Nederlandse en veertien Belgische klonen van populier. Wageningen: Instituut voor Bos- en Natuuronderzoek (ibn-dlo).

MINISTÈRE DE L'AGRICULURE ET DE L'ALIMENTATION 2019. Liste des vergers à graines, peuplements et clones admis en catégorie testée.

PUIJENBROEK, F. J. M. 1969. Onder de voet gelopen: het ontstaan en verdwijnen van een kleinnijverheid in Nederland na 1800 de Brabantse klompenmakerij, Tilburg, Stichting zuidelijk historisch contact.

RAHAYU, I., DENAUD, L., MARCHAL, R. \& DARMAWAN, W. 2014. Ten new poplar cultivars provide laminated veneer lumber for structural application. Annals of Forest Science, 72, 705-715.

RASSENLIJST BOMEN. 2020. Populus $x$ canadensis [Online]. Available: https://www.rassenlijstbomen.nl/nl/Home/Soorten/Soortendetails.htm?dbid=756\&typeofpage $=2142256$ [Accessed 26 oktober 2020].

SANNIGRAHI, P., RAGAUSKAS, A. J. \& TUSKAN, G. A. 2010. Poplar as a feedstock for biofuels: A review of compositional characteristics. Biofuels, Bioproducts and Biorefining, 4, 209-226.

STANTON, B. J., SERAPIGLIA, M. J. \& SMART, L. B. 2014. The domestication and conservation of Populus and Salix genetic resources. In: ISEBRANDS, J. G. \& RICHARDSON, J. (eds.) Poplars and Willows: Trees for Society and the Environment. Wallingford, Boston: CABI, FAO.

STEENACKERS, M. 2012. Advies betreffende de evolutie van populaties van de roestschimmel Melampsora larici-populina in Europa en de roestgevoeligheid van in Nederland gecommercialiseerde populiereklonen. Brussel: Instituut voor Natuur- en Bosonderzoek (INBO.A.2012.114).

STEENACKERS, M., DE CLERCQ, W. \& SCHAMP, K. 2018. De INBO variëteiten van populier, een aanwinst voor de Europese populierenteelt. Silva Belgica, 40-47.

STELSTRA, R. 2019. Suitability of Dutch poplar clones for acetylation purposes. BSc, Wageningen University \& Research.

TERRASSON, D. \& VALADON, A. 1998. Biologie et Forêt; Robusta, un centenaire méritant. Revue forestière française, 50, 105-111.

VAN HAAREN, H. A. J. 1987. Populieren in Nederland: eigenschappen en gebruikswaarde van de in bos, stad en landschap voorkomende soorten en klonen, Wageningen, Pudoc.

VERSTRAETEN, A., DE KEERSMAEKER, L. \& VANDERKERHOVE, K. 2003. Populieren, brandnetels en natuurbehoud: Omstreden positie van cultuurpopulieren onder de loep. Natuur Focus, 2, 37-41. 
CGN

Postbus 16

6700 AA Wageningen

cgn@wur.nl

www.wur.nl/cgn

Wageningen University \& Research CGN rapport 51
De missie van Wageningen University \& Research is 'To explore the potential of nature to improve the quality of life'. Binnen Wageningen University \& Research bundelen Wageningen University en gespecialiseerde onderzoeksinstituten van Stichting Wageningen Research hun krachten om bij te dragen aan de oplossing van belangrijke vragen in het domein van gezonde voeding en leefomgeving. Met ongeveer 30 vestigingen, 6.500 medewerkers ( $5.500 \mathrm{fte}$ ) en 12.500 studenten behoort Wageningen University \& Research wereldwijd tot de aansprekende kennisinstellingen binnen haar domein. De integrale benadering van de vraagstukken en de samenwerking tussen verschillende disciplines vormen het hart van de unieke Wageningen aanpak. 



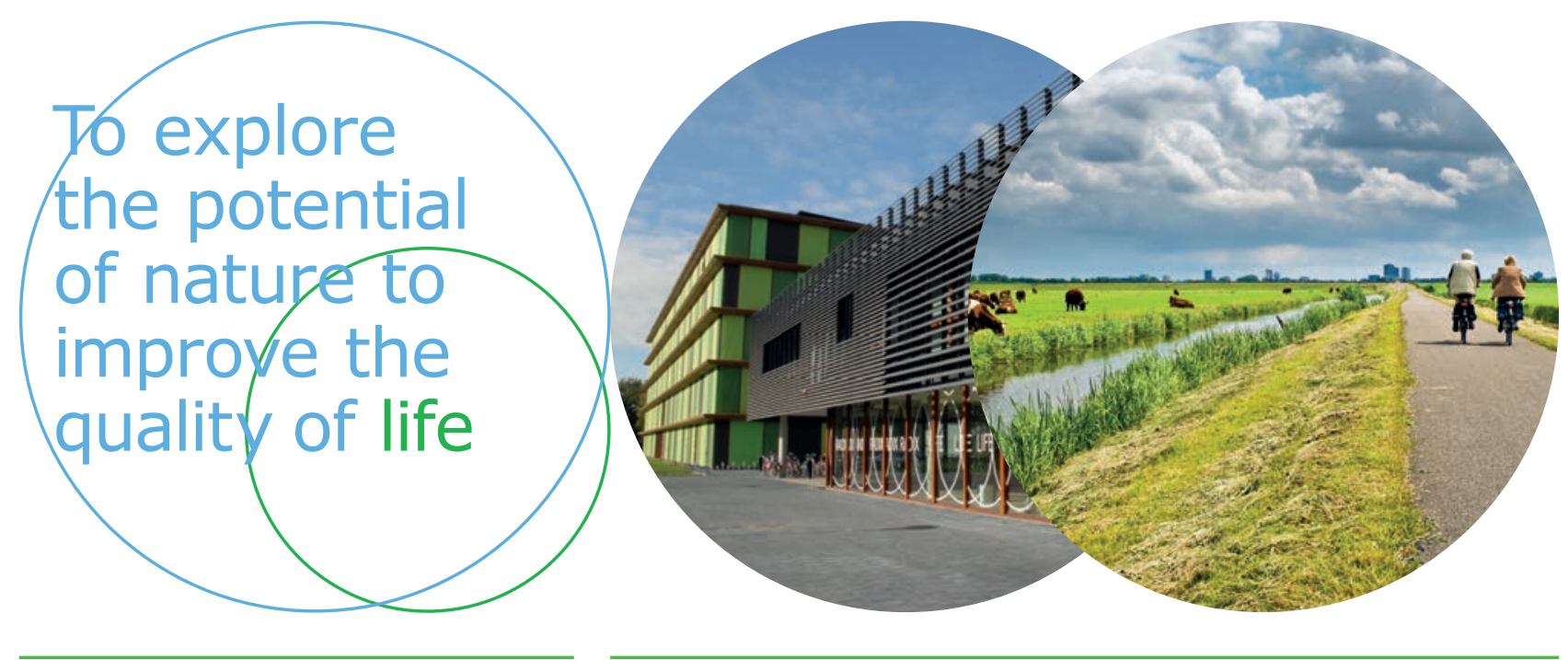

CGN

Postbus 16

6700 AA Wageningen

cgn@wur.nl

www.wur.nl/cgn

Wageningen University \& Research CGN rapport 51
De missie van Wageningen University \& Research is 'To explore the potential of nature to improve the quality of life'. Binnen Wageningen University \& Research bundelen Wageningen University en gespecialiseerde onderzoeksinstituten van Stichting Wageningen Research hun krachten om bij te dragen aan de oplossing van belangrijke vragen in het domein van gezonde voeding en leefomgeving. Met ongeveer 30 vestigingen, 6.500 medewerkers ( $5.500 \mathrm{fte}$ ) en 12.500 studenten behoort Wageningen University \& Research wereldwijd tot de aansprekende kennisinstellingen binnen haar domein. De integrale benadering van de vraagstukken en de samenwerking tussen verschillende disciplines vormen het hart van de unieke Wageningen aanpak. 